\title{
ON THE IDENTITY OF MYOXANTHUS SCANDENS (ORCHIDACEAE: PLEUROTHALLIDINAE), WITH A NEW SPECIES FROM COSTA RICA
}

\author{
Franco Pupulin ${ }^{1-4}$, Diego Bogarín ${ }^{1,2} \&$ Melania Fernández ${ }^{1}$ \\ ${ }^{1}$ Lankester Botanical Garden, University of Costa Rica \\ ${ }^{2}$ Ángel Andreetta Research Center on Andean Orchids, University Alfredo Pérez Guerrero, Ecuador \\ ${ }^{3}$ Harvard University Herbaria, Cambridge, MA, U.S.A. \\ ${ }^{4}$ Corresponding author: franco.pupulin@ucr.ac.cr
}

\begin{abstract}
We present and illustrate a new species of Myoxanthus from Costa Rica, closely related to $M$. scandens. We present descriptions and illustrations of both species. The new species, Myoxanthus sotoanum differs from M. scandens, by its linear leaves, the brownish-yellowish flowers, the yellow petals and lip, the oblong, obtuse, subfalcate lateral lobes of the lip, the two keels extending nearly to the middle of the lip, and the shorter, triangular, acute teeth that flank the stigma. Myoxanthus sotoanum generally also occurs at lower elevations than M. scandens.

RESUMEN: Presentamos e ilustramos una nueva especie de Myoxanthus para Costa Rica, junto a la descripción e ilustración de $M$. scandens basadas en material costarricense. La nueva especie, Myoxanthus sotoanum, es similar a $M$. scandens, de la que difiere principalmente por sus hojas lineares, las flores café-amarillento, los pétalos y el labelo amarillos, los lóbulos laterales del labelo oblongos, obtusos y subfalcados, las dos quillas que se extienden hasta la mitad del labelo y los dientes más cortos, triangulares, agudos, que flanquean el estigma. Myoxanthus sotoanum generalmente se encuentra a elevaciones inferiores que M. scandens.
\end{abstract}

KEY wORDS: Myoxanthus scandens, Costa Rica, Myoxanthus sotoanum, new species, Orchidaceae

Members of the subtribe Pleurothallidinae (Orchidaceae) are often taxonomically problematic. Both in herbaria and living collections, names of Pleurothallidinae are frequently applied without direct knowledge of the nomenclatural types. Moreover, the general overall similarity in the flowers of some groups and their usually reduced dimensions make more difficult a careful comparison between closely related taxa. The misunderstanding of the critical characters that allow taxonomic identification, the particular species concept used and an insufficient appreciation of natural variation, often lead to incorrect species circumscriptions. Under these circumstances, it is possible that undescribed species remain hidden under broadly defined taxonomical concepts.

In Costa Rica, the plants identified as Myoxanthus scandens Ames (Luer) are likely a fine example of this problem [Atwood, 1987, 1989 (both with illustration); Pupulin, 2002; Luer, 1976, 1982, 1992, 2003]. This species is member of a small group of Myoxanthus species characterized by the prolific, usually pendent stems, and mostly narrowly elliptic leaves, including M. chloë (Luer \& Vásquez) Luer, M. epibator Luer \& Escobar, M. fimbriatus Luer \& Hirtz, M. frutex (Schltr.) Luer, M. parvilabius (C. Schweinf.) Luer, and Pleurothallis pennellia Luer. With the exception of $M$. scandens, which ranges northward to Costa Rica, this group is eminently South American in distribution, with the highest diversity in the Andes from Colombia to Bolivia. Only one species, M. parvilabius, is known from the Guyana shield (Luer, 1992).

A. R. Endrés collected material later referred to as Myoxanthus scandens near the village of San Ramón, Costa Rica, around 1870. According to the collector's vouchers deposited in $\mathrm{W}$, the same species was also found in the vicinity of the old capital city of Costa Rica, Cartago. Over fifty years later it was collected again by Charles H. Lankester at La Estrella del Guarco, close to Cartago, and this specimen was eventually used by professor Ames to formally describe Myoxanthus scandens (as Pleurothallis scandens; Ames 1923). According to a manuscript note of the collector on the 
holotype sheet, the flowers of this species are "dull raisin purple".

After studying specimens of this group in the collections of CR, INB, JBL, USJ and W, we noted that the name was apparently applied to two different taxa, one having dark purple flowers and the other yellowish flowers. Further examination revealed additional distinguishing characters between these two taxa, both in vegetative and floral morphology. One of these species was recognized as Myoxanthus scandens, while the other is still in need of taxonomical recognition. With the aim of better comparing both entities, we describe and illustrate M. scandens as well as the species new to science.

Myoxanthus scandens (Ames) Luer, Selbyana 7(1): 49. 1982. Pleurothallis scandens Ames, Sched. Orch. 5: 18-21. 1923. Fig. $1-2$.

TYPE. Costa Rica. Cartago: La Estrella, C. $H$. Lankester \& A. Sancho 401 A delightful scandent species occurring in forest-ridges. Flowers dull raisin purple (holotype, AMES; isotype, AMES).

Plant epiphytic, caespitose, scandent, up to $60 \mathrm{~cm}$ long. Roots slender, flexuous, to $1 \mathrm{~mm}$ in diameter. Ramicauls slender, cylindric, $0.1-0.15 \mathrm{~cm}$ in diameter, 0.6-30.0 cm long, enclosed by 3-13 tubular, pubescent sheaths $0.5-4.5 \mathrm{~cm}$ long. Leaves straight with the ramicaul, coriaceous, elliptic, conduplicate, acute, $2.5-11.0 \times 0.5-1.0 \mathrm{~cm}$, narrowly cuneate basally, subpetiolate. Inflorescence a fascicle of successive, single flowers, borne at the apex of the ramicaul from a spathe $1 \mathrm{~mm}$ long, with flowers usually produced singly, 2-4 mm long including the peduncle $2 \mathrm{~mm}$ long. Floral bracts tubular, ovate, acute, conduplicate, pubescent, $1 \mathrm{~mm}$ long. Pedicels $1 \mathrm{~mm}$ long, persistent. Ovary cylindric, $1.5 \mathrm{~mm}$ long. Flowers with brownpurple sepals and translucent green petals with longitudinalpurple stripes, the lip purple. Dorsal sepal ovate, acute, concave, $4.5 \times 2.0 \mathrm{~mm}$, 5-veined. Lateral sepals ovate, acute to obtuse, $4.0 \times 1.5 \mathrm{~mm}, 3$ to 5 -veined, connate for approximately half their length, pubescent at the center of their common surface, the apex erose. Petals narrowly ovate, wider at the basal half, contracted into a thickened, apical, serrulate, acute tail, $4.0 \mathrm{~mm}$ long, $2.0 \mathrm{~mm}$ wide at the basal half. Lip oblong, scarcely trilobed, $3.0 \mathrm{~mm}$ long, hinged to the column foot, the lateral lobes near the middle, perpendicular, erect, the disc with a longitudinal pair of parallel lamellae from the lower third to near the apex, the base subtruncate with a pair of small lobules, the apex obtuse, minutely denticulate. Column short, stout, semiterete, $2 \mathrm{~mm}$ long, provided with an acicular, acuminate tooth on each side of stigma, the clinandrium denticulate, the anther incumbent, the stigma ventral. Pollinia two, pyriform, on an elliptic, recurved viscidium.

Material Studied: Costa Rica. Alajuela: [San Ramón], La Palma de San Ramón, [1300-1500 m], 29 Agosto 1924, A. M. Brenes 2291 (CR-34052). [Alajuela: San Ramón], La Palma de San Ramón, [1300-1500 m], 24 octubre 1924, A. M. Brenes 1536 (CR-26204). Cartago: $5.6 \mathrm{~km}$ San José side of road leading to Palmital, steep new dirt road up hill from Pan Am highway, 1700-1800 m, epiphytic on exposed tree near edge of forest. Plants to $1 \mathrm{~m}$ tall, upright - spreading, flowers extremely dark maroon almost black, 21 Setiembre 1979, K. S. Walter 79486 (CR). Oreamuno, Cipreses, $9^{\circ} 52^{\prime} 57^{\prime} \mathrm{N}, 83^{\circ} 51^{\prime} 18^{\prime}$ ' W, $1850 \mathrm{~m}$, remnants of primary forest, 23 June 1998, F. Pupulin et al. 838 (JBL-Spirit). Oreamuno, Cipreses, 9॰52'57’N, 8351'18”'W, 1850 m, 23 June 1998, F. Pupulin et al. 837 (USJ). Turrialba, Torito, [ca. $10^{\circ} 00^{\prime} 00^{\prime \prime} \mathrm{N}, 83^{\circ} 42^{\prime} 00^{\prime \prime} \mathrm{W}, 1500 \mathrm{~m}$ ], floreció en cultivo en el Jardín Botánico Lankester, 25 enero 2001, M. Blanco 1820 (USJ). Heredia: Heredia, Vara Blanca, en los potreros y partes de bosque secundario pertenecientes al Poás Volcano Lodge cerca del centro

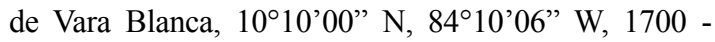
1900 m, 03 - 04 agosto 2006, Karremans 1322 \& D. Karremans (JBL-Spirit) (Fig. 2). Panama. Panama: road between El Llano and Cartí, 300 m, 4 Mar. 1976, C. Luer et al. 1018 (MO, SEL, illustration); Llano-Cartí road, 1 mile past saw mill on dirt road, 300-500 m, 11 Nov. 1979, C. Todzia et al. 1023 (CR).

Eтymology: From the Latin scandens, "scandent" in allusion to the habit of the plant.

Distribution: Costa Rica and Panama.

Habitat and ecology: Epiphytic in lower montane wet and very wet forests, and premontane rain forest at elevations between 1300 and $1900 \mathrm{~m}$ in Costa Rica, and epiphytic in premontane wet forests at elevations between 300 and $500 \mathrm{~m}$ in Panama. According to 

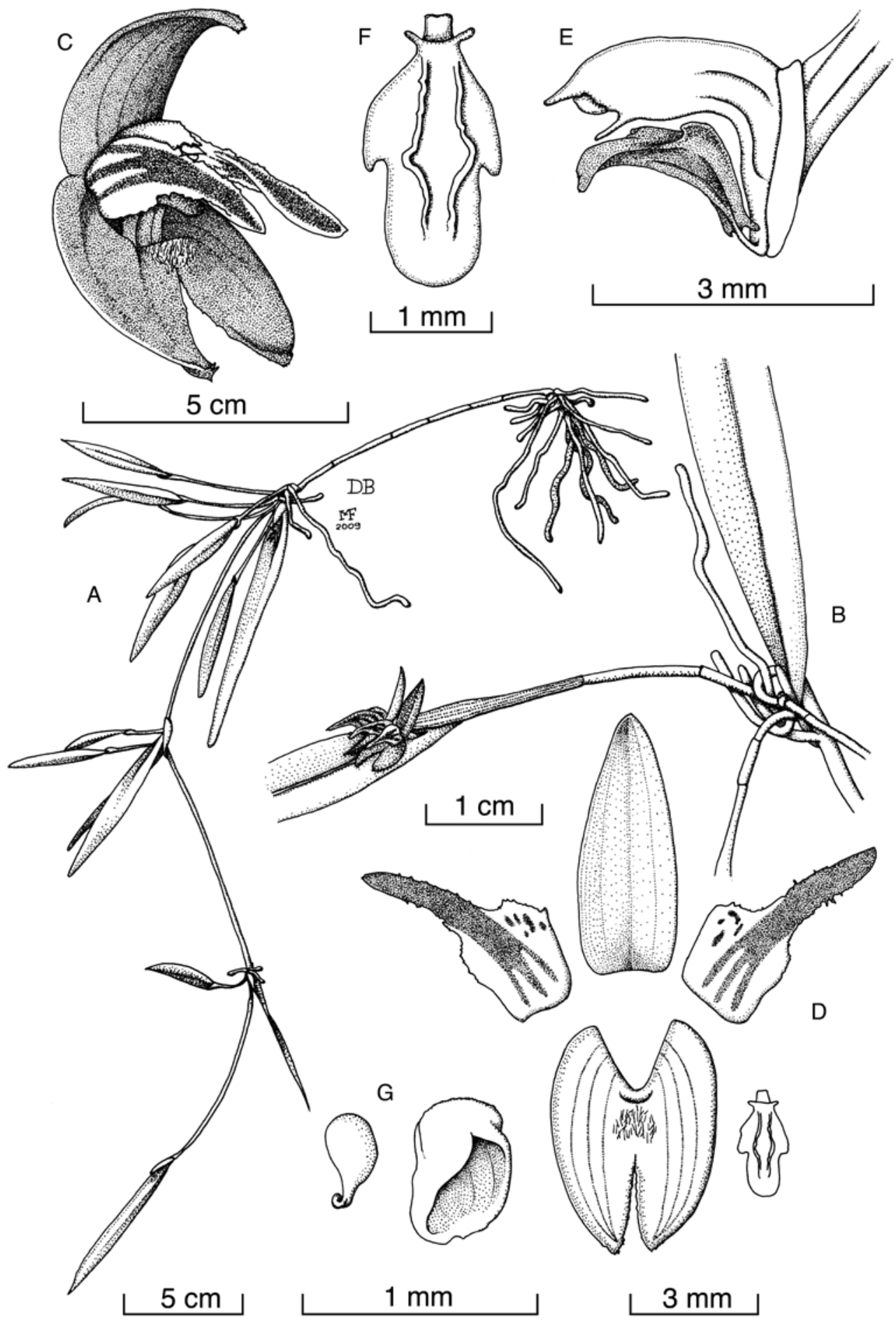

$\mathrm{B}$

Figure 1. Myoxanthus scandens (Ames) Luer. A - Habit. B - Detail of the habit. C - Flower. D - Dissected perianth. E - Ovary, column and lip, lateral view. F - Lip, spread. G - Pollinarium and anther cap. Drawn by D. Bogarín and M. Fernández from A. Karremans 1322. 


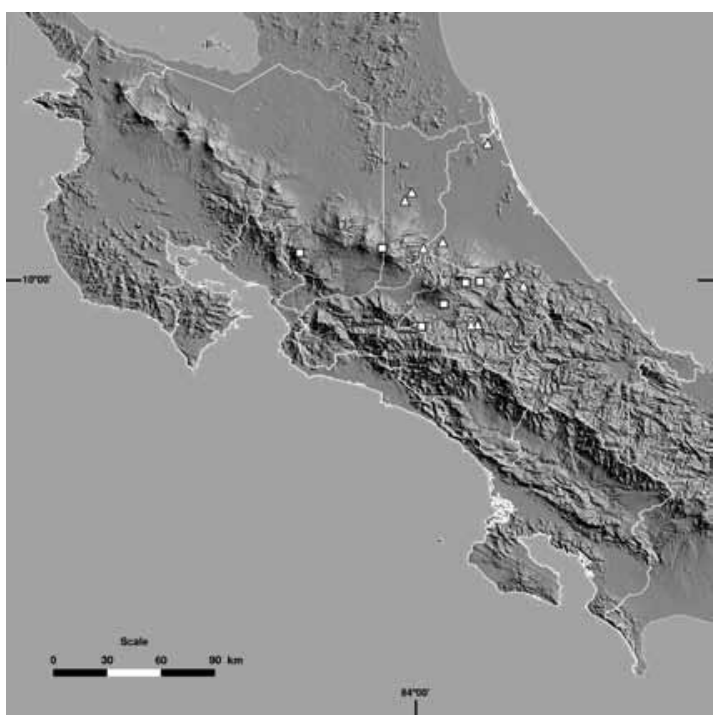

FIGURE 2. Distribution map of Myoxanthus sotoanum $(\triangle)$ and Myoxanthus scandens $(\square)$ in Costa Rica.

data available, this species flowers from December to February.

Myoxanthus scandens is distinguished by the elliptic leaves, dark purple flowers, the purple striped petals, lateral lobes of lip triangular, acute, erect with two keels extending to the apex of the lip, and the long, acuminate processes that flank the stigma.

We are not including here Pleurothallis pennellia in the synonymy of $M$. scandens. The species was described in 1976 from Ecuador, on the basis of a specimen flowered in cultivation at the Marie Selby Botanical Gardens (Luer, 1976). Luer (1976) noted the vegetative similarity to $M$. scandens, but described the new species as much less prolific. This, however, may be an artifact due to the juvenile, immature condition of the holotype specimen, and Luer later included it in the synonymy of M. scandens (Luer, 1992). The petals of $P$. pennellia are narrowly ovate and shortly obtuse at the apex, while in both M. scandens and M. sotoanum they are apically contracted into a thickened, acute tail. The lip of P. pennellia has two low keels above the middle, while these structures extend from the lower third to the middle of the lip in M. sotoanum, and from the base to near the apex in M. scandens. Furthermore, the clinandrium of $P$. pennellia is short, leaving the anther partially exposed, while $M$. scandens and $M$. sotoanum have a long, hooded clinandrium, completely covering the anther cap. In our opinion, P. pennellia is a true member of Myoxanthus, likely distinct from other species of the genus. It is perhaps co-specific with a Peruvian (or perhaps an Ecuadorian), unvouchered specimen illustrated in Zelenko \& Bermúdez (2008). However, we refrain to make the new combination in Myoxanthus until we can study more material from the type locality.

Myoxanthus sotoanum Pupulin, Bogarín \& $M$. Fernández $s p$. nov.

TYPE: Costa Rica. Cartago: Jiménez, Pejibaye, La

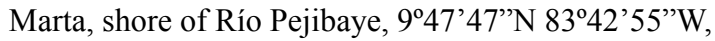
$690 \mathrm{~m}$, epiphytic in secondary vegetation along the river, premontane wet forest, 10 Jan. 2004, F. Pupulin 5044, S. Dalström \& H. León-Páez (holotype, CR; isotype, JBL-spirit). Fig. 2-3.

Species Myoxantho scandenti (Ames) Luer aemulans, sed foliis linearibus, sepalis brunneis, petalis labelloque flavis, lobis lateralibus labelli obtusis subfalcatis, duobus carinis extensis fere dimidium labelli, dentibus lateralibus columnae acicularis acuminatis praecipue differt.

Plant epiphytic, cespitose, scandent, up to $90 \mathrm{~cm}$ long. Roots slender, flexuous, to $1 \mathrm{~mm}$ in diameter. Ramicauls slender, cylindric, $0.5 \mathrm{~cm}$ in diameter, $1-23$ cm long, enclosed by 2-6 tubular, pubescent sheaths $0.8-4.0 \mathrm{~cm}$ long. Leaves straight with the ramicaul, coriaceous, elliptic, conduplicate, acute, 2.5-9.0 x 0.15$0.3 \mathrm{~cm}$, narrowly cuneate, subpetiolate. Inflorescence a fascicle of successive, single flowers, borne at the apex of the ramicaul from a spathe 1.0-1.5 $\times 0.1-0.25$ $\mathrm{mm}$, with flowers usually produced singly, 4-6 mm long including the peduncle $2 \mathrm{~mm}$ long. Floral bracts tubular, ovate, acute, conduplicate, pubescent, $1 \mathrm{~mm}$ long. Pedicels $2 \mathrm{~mm}$ long, persistent. Ovary cylindric, $2 \mathrm{~mm}$ long. Flowers with brownish-yellowish sepals and yellow petals and lip. Dorsal sepal ovate, acute, entire, concave, $5.0 \times 2.0-2.5 \mathrm{~mm}, 3$ to 5 -veined. Lateral sepals ovate, acute to obtuse, entire, concave, $4.5 \times 2.0 \mathrm{~mm}, 2$ to 3 -veined, connate and pubescent at the center of their common surface. Petals ovate, wider at the basal half, gradually contracted into a thickened, apical, serrulate, acute tail, 4-6 mm long, 1-2 mm wide at the basal half. Lip oblong, trilobed, 2.5 $\mathrm{mm}$ long, hinged to the column foot, the lateral lobes basal, perpendicular to the disc, erect, the disc with a 

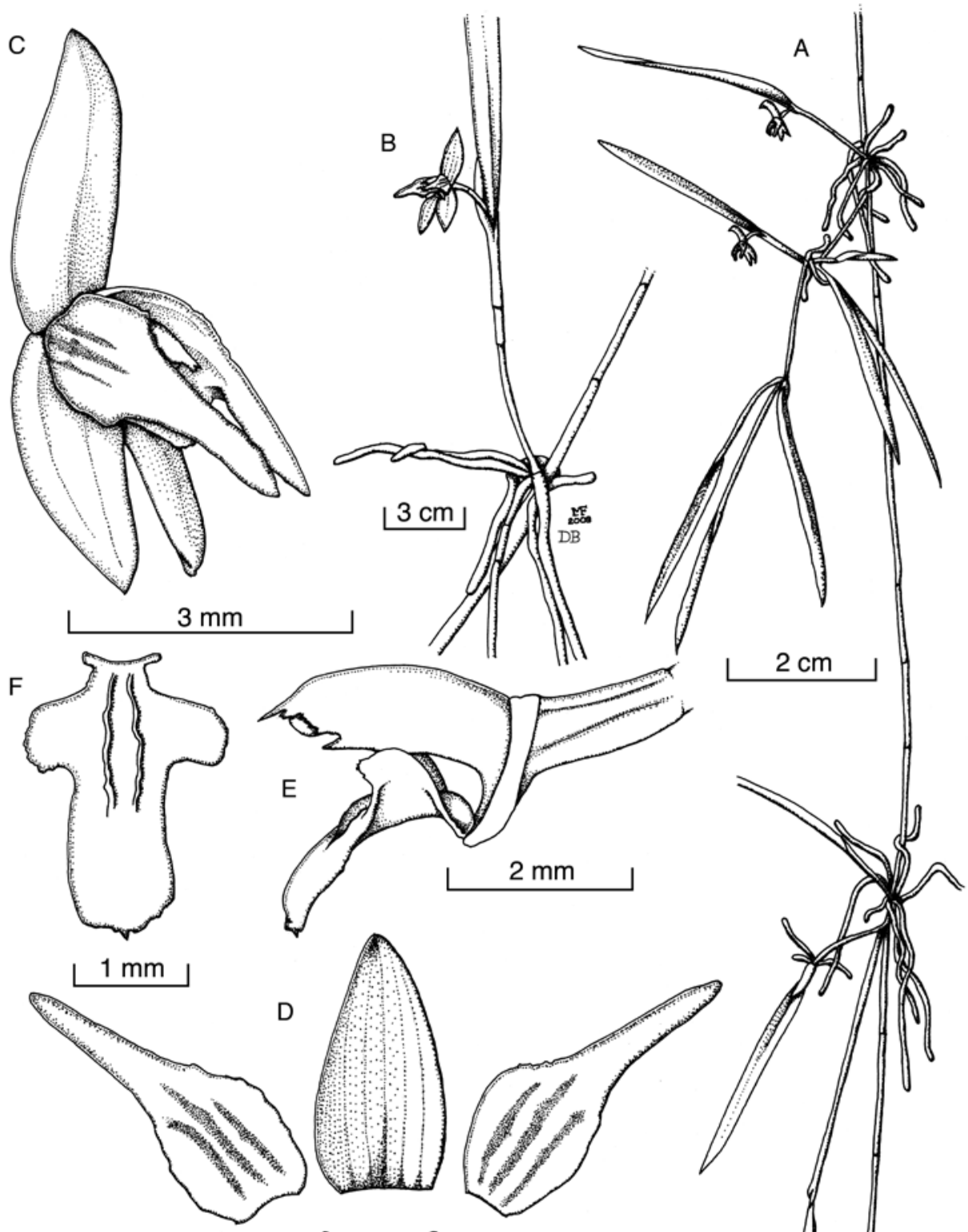

G
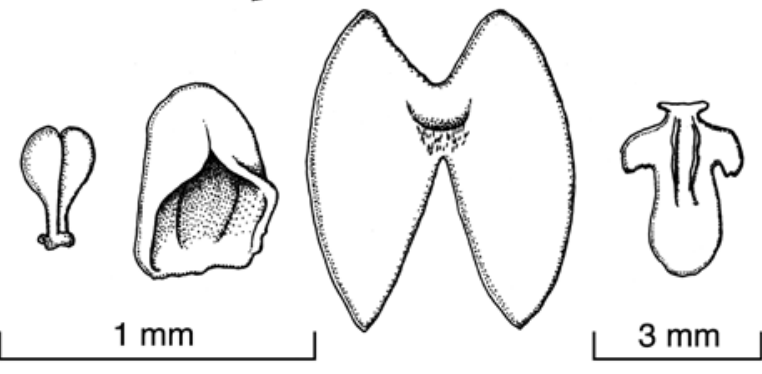
longitudinal pair of parallel lamellae from the lower third to the middle, the base subtruncate with a pair of small lobules, the apex obtuse, the apex minutely and irreguralrly erose. Column short, stout, semiterete, 2 $\mathrm{mm}$ long, provided a triangular, acute tooth on each side of stigma, the clinandrium denticulate with a pair of slender, apical teeth, the anther incumbent, the stigma ventral. Pollinia two, pyriform, on a rounded viscidium.

Paratypes: Costa Rica. Cartago: forest on Casa de Tejas Ridge above río Gato, 9०47’ $\mathrm{N} 83^{\circ} 41^{\prime} \mathrm{W}, 800$ m, 28 December 1973, W. Lent 3710 (CR). Jiménez, Pejibaye, Taus, Río Pejibaye, $1 \mathrm{~km}$ después de la escuela de Taus, 946'51.7'N 8343'00.4'W, 707 m, 30 abril 2009, D. Bogarín et al. 6920 (JBLSpirit). Turrialba, Parque Nacional Barbilla, cuenca del [río] Matina, sendero Principal por río Dantas, $9^{\circ} 58^{\prime} 20.0^{\prime} \mathrm{N}$ 8327'10.0” W, 300-400 m, epífita, flor blanca, 11 Noviembre 2000, G. Mora \& E. Rojas 1655 (INB). Turrialba, Parque Nacional Barbilla, cuenca del [río] Matina, sendero Barbilla, hasta la loma, 9॰58'20.0”'N 8327'10.0” W, 300-400 m, epífita, flor blanca, 20 Noviembre 2000, G. Mora \& E. Rojas 1722 (INB). Heredia: Finca La Selva, OTS Field Station near junction of Puerto Viejo and Sarapiquí rivers, 40-100 m, Camino Circular Lejano 750, 19 marzo 1991, K. Richardson 111 (CR). Finca La Selva, OTS Field Station near junction of Puerto Viejo and Sarapiquí rivers, 40-100 m, Camino Circular Lejano 750, 19 Marzo 1991, K. Richardson 113 (CR). Sarapiquí, La Virgen, Magsasay, banks of Río Peje, $10^{\circ} 24^{\prime} 03.9^{\prime \prime N} 84^{\circ} 02$ '53.5”W, $110 \mathrm{~m}$, tropical wet forest, 25 August 2007, F. Pupulin et al. 6888 (JBL-Spirit). Limón: Cerro Coronel, east of Laguna Danto, $10^{\circ} 41^{\prime} \mathrm{N} 83^{\circ} 38^{\prime} \mathrm{W}, 20-170 \mathrm{~m}$, tall evergreen forest on gentle to moderately steep slopes, scandent epiphyte in canopy, flowers white, 15-20 September 1986, W. D. Stevens 24568 (CR). Siquirres, Siquirres, Guayacán, en potreros bajando el camino frente el bar Guayacán, en las orillas de la Quebrada Quebrador, $10^{\circ} 02^{\prime} 1.44^{\prime \prime} \mathrm{N} 83^{\circ} 32^{\prime} 13.5^{\prime}$ " W, 477 m, 25 enero 2008, D. Bogarín $4049 \& A$. Karremans (JBL-Spirit). Siquirres, Guayacán, en potreros bajando el camino frente el bar Guayacán, en las orillas de la Quebrada Quebrador, $10^{\circ} 02^{\prime} 1.44^{\prime \prime} \mathrm{N}$ $83^{\circ} 32^{\prime} 13.5^{\prime}$ W, 477 m, 25 enero 2008, A. Karremans 2311 \& D. Bogarin (JBL-Spirit). Pococí, Cuenca del [río] Sarapiquí, Guápiles, finca INBio, sendero de Las Aves, 10¹1'39.624”N 8351'39.0980”'W, 300-400 m, epífita, flores blanco y morado, 07 Junio 2007, M. M. Flores et al. 24 (INB). San José: [Parque Nacional Braulio Carrillo], sendero "La Botella", 750 $\mathrm{m}$, floreció en cultivo en el Jardín Botánico Lankester, 10 Diciembre 2000, M. Blanco 1725 (JBL-Spirit, USJ). Sin datos de recolecta, floreció en cultivo en el Jardín Botánico Lankester, 30 setiembre 2009 (JBL21345-Spirit). Without collecting data, flowered in cultivation at Jardín Botánico Lankester, flowers pale yellow suffused with brown, 18 December 2000, F. Pupulin 2742 (USJ). Vásquez de Coronado, Parque Nacional Braulio Carrillo, along sendero "La Botella", in primary forest, $10^{\circ} 10^{\prime} 00^{\prime \prime} \mathrm{N} 83^{\circ} 57^{\prime} 20^{\prime \prime} \mathrm{W}$, $750 \mathrm{~m}$, epiphytic on liana, sepals translucent white suffused with purple, petals dull white, arching with apices meeting in front of lip, lip yellowish-white, 16 November 1990, S. Ingram 712 \& K. Ferrell (CR). Vásquez de Coronado, Parque Nacional Braulio Carrillo, along sendero "La Botella", in primary forest, $10^{\circ} 10^{\prime} 00^{\prime \prime} \mathrm{N} 83^{\circ} 57^{\prime} 20^{\prime}$ 'W, $750 \mathrm{~m}$, pale greenyellow suffused with purple spots, 02 January 1991, S. Ingram $828 \&$ K. Ferrell (INB).

Distribution : Known only from Costa Rica along the Caribbean slopes of the Central Volcanic Cordillera to about $800 \mathrm{~m}$

Eponymy: Dedicated to the memory of Miguel Angel Soto Arenas (1963-2009), for his outstanding contributions to the knowledge of Neotropical orchids.

Habitat And ecology: Plants have been found epiphytic in tropical wet and very wet forests, premontane rain forest, and premontane wet and very wet forest from near sea level to about $800 \mathrm{~m}$. Flowers between March and September.

Myoxanthus sotoanum is similar to M. scandens Ames, from which it differs in the linear leaves (vs. elliptic), brownish-yellowish flowers (vs. dark purple), the yellow petals and lip (vs. purple striped), oblong, obtuse, subfalcate lateral lobes of lip (vs. triangular, acute, erect) with two keels extending nearly to the middle of the lip (vs. extending to the apex of the lip), and the triangular, acute teeth (vs. acicular, acuminate) that flank the stigmatic cavity. It also generally occurs at lower elevations. 
ACKNOWLEDGEMENTS. The scientific services of Ministerio del Ambiente, Energía y Telecomunicaciones de Costa Rica (MINAET) and Sistema Nacional de Áreas de Conservación (SINAC) for issuing the collecting permits and Scientific Passports under which wild species treated in this study were collected. The observations and suggestions by Mario A. Blanco greatly improved the manuscript.The present paper is part of the Project 814-A7-015, "Inventario y taxonomía de la flora epífita de la región Neotropical - Orchidaceae", sponsored by the Vice-Presidency of Research, University of Costa Rica.

\section{LITERATURE CITED}

Ames, O. 1923. New or noteworthy orchids from Central America and the Philippine Islands. Schedul. Orch. 5: $18-21$.

Atwood, J. T. 1987. The vascular flora of La Selva Biological Station, Costa Rica. Orchidaceae. Selbyana 10: 76-145.
Atwood, J. T. 1989. Myoxanthus scandens (Ames) Luer. Icon. Pl. Trop.: plate 1373.

Luer, C. A. 1976. Miscellaneous species of Pleurothallis. Selbyana 3(1-2): 38-201.

Luer, C. A. 1982. A reevaluation of the genus Myoxanthus (Orchidaceae). Selbyana 7(1): 34-54.

Luer, C. A. 1992. Icones Pleurothallidinarum IX. Systematics of Myoxanthus. Addenda to Platystele, Pleurothallis, subgenus Scopula and Scaphosepalum (Orchidaceae). Monogr. Syst. Bot. Missouri Bot. Gard. 44: 1-128.

Luer, C. A. 2003. Myoxanthus. In: Hammel, B. E. Grayum, M. H., Herrera, C. \& Zamora, N. (eds.). Manual de Plantas de Costa Rica, vol III: Monocotiledóneas (Orchidaceae-Zingiberaceae). Missouri Bot. Gard. INBio. Museo Nacional de Costa Rica. Pp. 339-342.

Pupulin, F. 2002. Catálogo revisado y anotado de las Orchidaceae de Costa Rica. Lankesteriana 4:1-88.

Zelenko, H. \& P. Bermúdez. 2008. Orchids: Species of Peru. ZAI Publications. $407 \mathrm{p}$. 
LANKESTERIANA 